\title{
Collection and dissemination of fisheries data in support of the EU Common Fisheries Policy
}

\author{
Hendrik Dörner ${ }^{1, *}$, John Casey ${ }^{1}$, Natacha Carvalho ${ }^{1}$, Dimitrios Damalas ${ }^{2}$, \\ Norman Graham ${ }^{3}$, Jordi Guillen ${ }^{1}$, Steven J. Holmes ${ }^{1}$, Fabrizio Natale ${ }^{4}$, Giacomo C. \\ Osio $^{1}$, Hans-Joachim Rätz ${ }^{5}$, Cristina Ribeiro ${ }^{6}{ }^{\text {, Paraskevas Vasilakopoulos }}{ }^{1}$ \\ ${ }^{1}$ Unit D.02 Water and Marine Resources, Directorate D - Sustainable Resources, DG Joint Research Centre (JRC), \\ European Commission, 21027 Ispra (VA), Italy \\ ${ }^{2}$ Institute of Marine Biological Resources \& Inland Waters, Hellenic Center for Marine Research, Aghios Kosmas, \\ 16777 Athens, Greece \\ ${ }^{3}$ Marine Institute, Rinville, Oranmore, Co. Galway, H91 R673, Ireland \\ ${ }^{4}$ Unit E.06 Demography, Migration and Governance, Directorate E - Space, Security and Migration, \\ DG Joint Research Centre (JRC), European Commission, 21027 Ispra (VA), Italy \\ ${ }^{5}$ Thünen Institute of Sea Fisheries, Palmaille 9, 22767 Hamburg, Germany
}

${ }^{6}$ Fisheries and Information Branch, Food and Agriculture Organization of the United Nations (FAO), 00153 Rome, Italy

\begin{abstract}
A systematic European Union (EU)-wide data framework for the collection of fisheries data in support of the EU Common Fisheries Policy (CFP) was first implemented in 2002. Since that time, EU data collection regulation has undergone 2 revisions in response to evolving policy needs. The European Commission's Joint Research Centre (JRC) is responsible for conducting research and providing advice on fisheries management under the CFP, and since 2005 has worked closely with the Scientific, Technical and Economic Committee for Fisheries (STECF). JRC and STECF have an open data policy, and aggregated data submitted by EU member states in response to data calls issued under the provisions of the data collection regulation are published via the website of the STECF. This paper provides an overview of the fisheries data activities carried out by the JRC in support of and in collaboration with the STECF and discusses some of the benefits and drawbacks of such activities.
\end{abstract}

KEY WORDS: Common Fisheries Policy - CFP - Data Collection Framework - DCF - Scientific, Technical and Economic Committee for Fisheries - STECF - Scientific advice - Fisheries management $\cdot$ Fisheries policy $\cdot$ Open data policy

\section{INTRODUCTION}

Managing the exploitation of fish and shellfish stocks in European marine waters falls under the European Union (EU)'s Common Fisheries Policy (CFP), which was formally established in 1983 (Council of the European Communities 1983), and has since undergone reforms in 1992, 2002, and most recently in 2013 (EU 2013). The scope of the CFP extends to joint conservation, management and

\footnotetext{
${ }^{*}$ Corresponding author: hendrik.doerner@ec.europa.eu
}

exploitation of living aquatic resources by EU member states, and the overarching objective for fisheries under the CFP are those of biological, economic and social sustainability. Since the entry into force of the Lisbon Treaty in 2009 (EU 2007a), regulations, directives and decisions are adopted following the ordinary legislative procedure, formerly known as the co-decision procedure (i.e. Council of the EU and the European Parliament are co-legislators) (EU 2016). Nowadays, this procedure applies to all fisheries leg-

() The authors 2018. Open Access under Creative Commons by Attribution Licence. Use, distribution and reproduction are unrestricted. Authors and original publication must be credited. 
islation, except for the setting of annual fishing opportunities (total allowable catches [TACs]), which is the sole responsibility of the Agriculture and Fisheries Council of the EU (AGRIFISH), which comprises the relevant ministers from each EU member state. The Directorate-General for Maritime Affairs and Fisheries (DG MARE) is the European Commission's department responsible for implementation of the CFP, which explicitly requires the Commission to take 'into account available scientific, technical and economic advice' (EU 2013, p. 32) when drafting legislative proposals for the European Parliament and Council. Accordingly, European Commission proposals relating to fisheries management must be based on scientific advice, and hence implementation of the CFP requires both the assistance of specialised, independent experts and the availability of high-quality data and analyses. The European Commission's own expert scientific advisory committee on fisheries and aquaculture is the Scientific, Technical and Economic Committee for Fisheries (STECF). The Commission's Joint Research Centre (JRC) plays a key role in the scientific advisory process by providing advice directly to DG MARE, through participation in the STECF and its Expert Working Groups (EWGs) (see Fig. 1 for overview). This paper provides an overview of the fisheries data activities carried out by the JRC in support of and in collaboration with the STECF.

\section{STECF-JRC: LEGAL BASIS, MANDATE, AND ACTIVITIES}

Prior to 1993, the Commission's scientific advisory body for fisheries matters was the Scientific and Technical Committee for Fisheries (STCF), which was established in 1979 (European Commission 1979). The STECF was established by European Commission Decision 93/619 (European Commission 1993), partly in recognition of the growing importance of economics in EU fisheries management decision-making. The 2002 reform of the CFP (EU 2002a) gave the STECF a renewed mandate (European Commission 2005a), including the provision of advice on data collection in the fields of fisheries and aquaculture. The STECF should be consulted on matters pertaining to conservation and management of living aquatic resources, including biological, economic, environmental, social

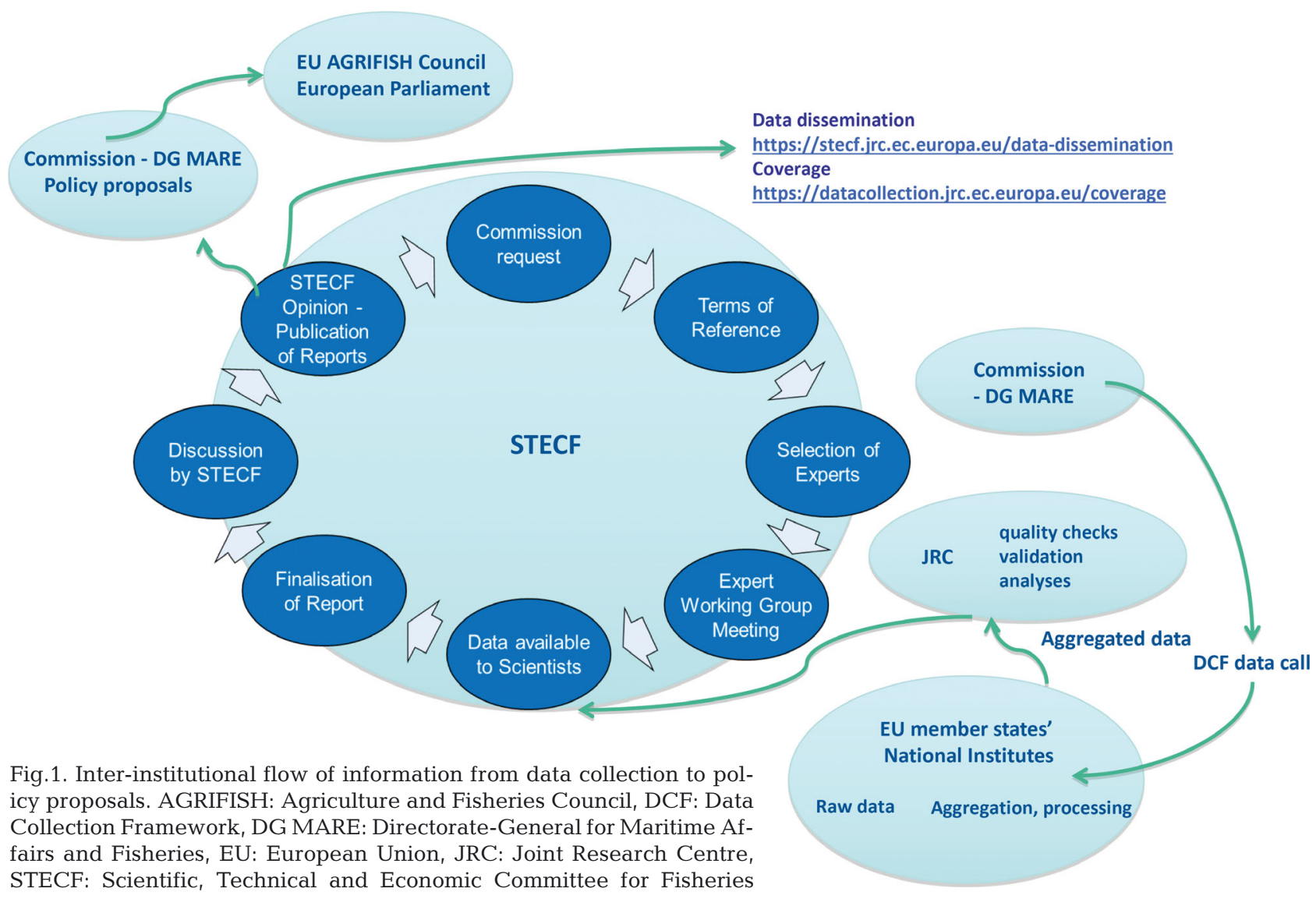


and technical considerations. The mandate also stated that the European Commission should consider such advice when presenting proposals on fisheries management under the CFP to the Council and/or the European Parliament. The current STECF was established following the CFP reform of 2013 (EU 2013, European Commission 2016a). The mandate of the STECF since then includes the provision of advice on any matter relating to marine and fisheries biology, fishing gear technology, fisheries economics, fisheries governance, ecosystem effects of fisheries, and aquaculture. More specifically, it also includes multi-annual management plans, measures relating to landing obligations, mixed fisheries management, the position of the EU at international fisheries organisations as well as sustainable fisheries partnership agreements with third countries (European Commission 2016a).

Since 2005, the secretariat for the STECF has been provided by the JRC. The tasks of the secretariat include planning, coordination, front-office and information and data dissemination activities. The JRC makes a significant contribution to the scientific and technical work of the STECF by managing EU-wide data calls issued by DG MARE (see sections on data collection below), by developing and applying data validation tools and undertaking statistical data checks. The JRC also maintains the data provided under such calls in dedicated databases and provides expert participants and chairs to EWGs of STECF. It also makes the data used by the STECF and its EWGs publicly available as electronic annexes to EWG reports and through dedicated dissemination platforms that facilitate interactive data exploration and downloading.

\section{DATA COLLECTION AND CFP}

The provision of advice for fisheries management under the CFP is dependent on the collection and availability of high-quality fishery-dependent and fishery-independent data, which are collected and owned by the EU member states under the provisions of the EU-wide data framework for the collection of fisheries data (Data Collection Framework [DCF]). Providers of independent scientific advice, such as the International Council for the Exploration of the Sea (ICES) and regional fisheries management organisations (RFMOs) (e.g. the General Fisheries Council for the Mediterranean [GFCM]), and scientific advisory bodies such as the STECF are regular end-users (see Table 1 for 'end-user' definition) of DCF data. Data are provided to end-users by EU member states in response to specific data calls. Prior to 2002, end-users of fisheries data had to rely on a limited number of largely uncoordinated scientific data sets, collected either under national programmes or in the context of specific ad hoc biological studies funded by the European Commission. The absence of an EU-wide and systematic framework for the collection of fisheries data meant that data collection approaches and sampling methodologies in EU member states were not harmonised, and the coverage and continuity of data collection was dependent on the availability of adequately funded national programmes. In addition, this process did not guarantee that once collected, the data would always feed into the scientific advisory process in an efficient and timely manner (European Commission 2005b). The situation improved with the introduction of the predecessor to the DCF, the EU Data Collection Regula-

Table 1. Definitions and explanations of Data Collection Framework (DCF)-related terms. CFP: Common Fisheries Policy, EU: European Union

\begin{tabular}{ll} 
Term & Definition/explanation \\
\hline End-user & $\begin{array}{l}\text { Article 2(i) of EU (2018): 'end-users' means bodies with a research or management interest in } \\
\text { the scientific analysis of data in the fisheries sector }\end{array}$ \\
$\begin{array}{c}\text { EU member states' DCF } \\
\text { national correspondents }\end{array}$ & $\begin{array}{l}\text { Article } 25 \text { of the CFP Regulation (EU 2013): Member states shall ensure the national coordi- } \\
\text { nation of the collection and management of scientific data for fisheries management, including } \\
\text { socio-economic data. To this end, they shall designate a national correspondent and organise } \\
\text { an annual national coordination meeting }\end{array}$ \\
& $\begin{array}{l}\text { A group of vessels using mainly the same fishing technique and within the same vessel length } \\
\text { Flegory (see STECF 2017a) }\end{array}$ \\
Métier/pseudo-métier segment & $\begin{array}{l}\text { Métier: a group of fishing operations targeting a similar (assemblage of) species, using similar } \\
\text { gear (as specified in Annex XI of Regulation (EU) No 404/2011) during the same period of the } \\
\text { year and/or within the same area and which are characterised by a similar exploitation pattern } \\
\text { (European Commission 2011, 2016b). Pseudo-métier: vessels grouped according to vessel } \\
\text { length group, gear type, mesh size (where appropriate) and catch composition }\end{array}$
\end{tabular}


tion (DCR), which extended from 2002 to 2008 (EU 2000). Under this framework, the national fisheries research institutes of EU member states conducted regionally and internationally coordinated sampling programmes, which were co-financed up to $50 \%$ by the European Commission.

The DCR introduced provisions specifying the data to be collected, the levels of aggregation, and the transmission of the data to the end-users in response to data calls to EU member states. With these provisions, the DCR established a more systematic fisheries data collection system for the entire EU. In terms of data provision to the end-users, the DCR had limitations, since it prescribed that once submitted by member states, the data could be kept only for $20 \mathrm{~d}$ and used only in the context of the specific scientific consultation for which it was requested. The first data calls under the DCR to support the work of STECF took place in 2005 when the JRC assumed responsibility for the secretariat of STECF and started to service data calls issued by DG MARE. Due to the $20 \mathrm{~d}$ rule, data sets had to be requested repeatedly and end-users would spend a considerable amount of time assembling data rather than analysing it.

Data calls under the DCR concerned EU fishing fleet economics, fishing effort regimes, and catch information in selected fisheries. Such data calls acted as a learning process for end-users in formulating exactly what should be requested, for the JRC in managing calls associated with the STECF and for member states to respond to the calls in the required timeframe.

A major milestone towards the provision of data to inform the scientific advisory process was reached with the implementation of the 2nd EU Data Collection Framework Regulation (DCF) in 2009 (EU 2008a, European Commission 2008, 2009). One of its main purposes was to further improve the access, exchange, and utility of EU fishery-dependent and fishery-independent data for scientific advice for fisheries management purposes, and among other things, it abolished the $20 \mathrm{~d}$ data retention. Both DCR and DCF were co-financed by the member states and the European Commission. Co-financing by the European Commission was raised to $80 \%$ (under the European Maritime and Fisheries Fund [EMFF]) (EU 2014), compared to the DCR period with $50 \%$ under the minimum and $35 \%$ under an extended programme. With the new DCF in place, the JRC started to develop and maintain databases to store time series of economic data for the EU fishing fleet, aquaculture and fish processing sectors, biological and transversal data (capacity, effort, and landings) for the evaluation of fishing effort management regimes, and biological, transversal and survey data for Mediterranean and Black Sea fish stock assessments. At the same time, the JRC was able to develop and apply automatic data validation tools and undertake statistical data checks, e.g. in order to check member states' data submissions against the required data formats specified in the data calla and to identify outliers in the data. In addition, the JRC started to make the data used by the STECF and its EWGs publicly available in aggregated form as electronic annexes to STECF reports and through online dissemination platforms, which facilitate interactive data exploration and downloading by anybody potentially interested. Nowadays, DG MARE, academia, industry, national administrations, and nongovernmental organisations (NGOs) frequently use the dissemination platforms.

\section{DATA COLLECTION AND STECF}

Transmission of EU member states' data used for detailed analyses by end-users such as ICES and GFCM is in response to specific data calls. Data calls in support of the STECF are issued by the Commission/DG MARE. Such data calls are designed to provide the data required to address the specific terms of reference given to STECF. When responding to data calls, EU member states provide data in aggregated form according to the data call specifications and must submit the data within a predefined timeframe. The JRC facilitates the data calls by providing uploading facilities, data validation tools, and carrying out automatic and manual data-quality checks. Subsequent to the quality checks and when necessary, resubmission of amended data sets by the EU member states may be requested. The JRC provides the approved data sets to the relevant STECF EWGs, where they form the basis of the STECF analyses and advice. The aggregated data sets are then made available to the public at the same time as the reports from the STECF are published.

The data transmissions by the EU member states in response to DG MARE data calls are assessed by the JRC for coverage, by STECF experts for consistency and completeness, and by DG MARE for compliance in respect to DCF legal obligations.

To further improve efficiency in the process, in spring 2015, the JRC, DG MARE, and STECF devised a data submission and updating procedure with clearly defined deadlines. The proposal was pre- 
sented and welcomed by the EU member states' DCF national correspondents (see Table 1 for definition) and the Committee for Fisheries and Aquaculture. The Committee for Fisheries and Aquaculture consists of member states' representatives and was established by Article 47 of the CFP Regulation (EU 2013). It is a regulatory committee assisting the Commission. Implementing acts under the CFP prepared by the Commission need to be agreed by the Committee. Also, the EU member states' permanent representatives were duly informed on the devised data submission and updating procedure. As a result, in 2015, the data submission process was much improved compared to earlier years. Further details of the ongoing and planned data calls can be found on the data collection website hosted by the JRC (https://datacollection.jrc.ec.europa.eu/). The current institutional setting, workflow, and data flow from data collection at the EU member states level to the final product of STECF scientific advice is depicted in Fig. 1.

\section{ECONOMIC DATA}

\section{EU fishing fleet}

The STECF annual economic report (AER) provides a comprehensive overview of the economic performance of European fishing fleets. The AER data covers transversal (capacity, landings and effort) and economic data (income, costs, employment, capital value and investment). Data in the AER are reported aggregated at the fleet-segment level (see Table 1 for definition), and so it shows the evolution of a similar group of vessels. The AER includes a detailed structural overview and an assessment of the annual economic performance of each EU member state's fishing fleet, together with regional analyses by sea basin, and an EU overview with economic performance projections and indicators. With the observed increase in quality and coverage of data collected and reported under the DCF over the years, the AER has become the most important economic reference publication for policy decision-making in fisheries management under the CFP. The report is used by policy-makers in the European Commission and the European Parliament, as well as other stakeholders such as NGOs, international organisations, such as the Organisation for Economic Co-operation and Development (OECD) to monitor profitability trends in the EU capture-fisheries sector, and academia (e.g. Cardinale et al. 2013, Cheilari et al. 2013,
Hadjimichael et al. 2013, Vasilakopoulos et al. 2014, Guillen et al. 2016). The most recent AER was published in 2017 (STECF 2017a).

\section{Aquaculture and fish processing sectors}

Under the DCF, EU member states are also required to collect data on the aquaculture sector. Data on the fish processing sector was required under previous data collection regulations but is not compulsory under the current DCF. In most EU member states, data for both sectors are collected via surveys conducted by national statistical offices or other agencies or institutes. STECF analysed fish processing data for the first time in 2009, and then again in 2010, 2012, 2013 and 2014. The fish processing sector report provides information on structure (number of enterprises, employment) and economic data (income, costs, capital value and investment) of the companies whose main activity is fish processing. On a voluntary basis, some member states disaggregate the data by enterprise size (depending on the number of persons employed). The 2014 report on the economic performance of the EU fish processing industry (STECF 2014) was the fifth of its kind and provided a comprehensive overview of the latest information provided by EU member states on the structure, and social, economic and competitive performance of the fish processing industry at the national and EU level (Bjørndal et al. 2016).

In 2011, STECF analysed DCF economic data on the EU aquaculture sector for the first time. The aquaculture economic reports provide information on the structure (number of enterprises, employment), production in weight and value, raw materials, and economic data (income, costs, capital value and investment) of the companies whose main activity is aquaculture production. Data are segmented by the main species produced (salmon, trout, seabream and seabass, mussels, etc.) and the main technique (cages, hatcheries, etc.). The 2016 report on the economic performance of the EU aquaculture sector (STECF 2016) was the fifth of its kind and constitutes the most recent comprehensive overview of the information available on the production, economic value, structure and competitive performance of the aquaculture sector at the national and EU level (e.g. Bostock et al. 2016, Jennings et al. 2016, Lasner et al. 2017). Because providing data on the freshwater aquaculture sector is optional under the DCF (and landlocked countries do not participate), not all EU member states provided data regarding their full 
national aquaculture sectors, so the reported DCF data were supplemented using production data held by the statistical office of the EU (Eurostat) to provide a more complete overview of the aquaculture sector for all 28 EU member states.

\section{FISHERIES ASSESSMENT DATA}

A dedicated EWG known informally as the 'effort' EWG was established to allow the STECF to provide advice relating to the recovery and later, multiannual management plans for fisheries exploiting Atlantic cod Gadus morhua (EU 2004, 2008b). An associated database (the STECF effort database) was set up and hosted by the JRC in support of the STECF. Over time, the remit of the database extended to multi-annual management plans connected to fisheries exploiting plaice Pleuronectes platessa and common sole Solea solea in the North Sea (EU 2007b), sole in the Western Channel and Bay of Biscay (EU 2006, 2007c), the southern stock of European hake Merluccius merluccius and Norway lobster Nephrops norvegicus in the Cantabrian Sea and Western Iberian Peninsula (EU 2005), and Baltic cod (EU 2007d). Under the cod and North Sea plaice and sole plans, fishing effort ceilings (engine power in $\mathrm{kW} \times$ days-at-sea limits) were placed on fisheries, defined according to temporal and regional combinations of gear used, mesh size and species' catch composition. For other plans, fishing effort limits were expressed as days at sea (Western Channel sole), days absent from port (Baltic cod), fishing days or optionally $\mathrm{kW} \times$ fishing days (Southern hake) and capacity in gross tonnes (Bay of Biscay sole). The establishment of such plans created the need to monitor the following:

- trends in fishing effort,

- which gear and mesh size combinations were having the greatest impact on the relevant stocks,

- whether fishing effort limits were effective with regard to achieving the prescribed goals of the management plans,

- data quality in terms of coverage (completeness) and consistency of member states' data submissions.

To achieve the above objectives, data were required from fisheries that were regulated under management plans and unregulated fisheries. The Commission also called for data from the Celtic Seas region (ICES sub-area 7), according to the same gear categories as specified in the Atlantic cod plan, in anticipation of a possible (although never realised) introduction of an effort management regime in this area. Finally, data to monitor fishing activity related to the deep sea and western waters regulations (EU $2002 b, 2003)$ was integrated in the database. To provide more detail, data were also partitioned according to vessel length categories. Thus, the data were grouped into pseudo-métiers (see Table 1 for definitions of pseudo-métier and métier).

The specific requirement for the effort database was to be able to assess the impact of fishing effort allocations granted to certain métiers under the provisions of the recovery and management plans. Under the cod plan, EU member states were allocated a maximum amount of fishing effort expressed as $\mathrm{kW} \times$ days. However, groups of vessels that undertook to adopt certain technical modifications to fishing gears or to change their fishing behaviour with the aim of reducing catches (and fishing mortality) of cod were either granted additional effort allocations or were exempted from the effort regimes. Hence, there was a need to be able to assess whether adoption of such 'specific conditions' were effective in practice.

The effort database contains detailed information on fishing effort, and catches (landings and discards) by species, by pseudo-métier and (for landings and effort only) by ICES statistical rectangle, and has proved useful in capturing the evolution of catches and effort over the years and the impact of individual fisheries on many fish stocks, not only those subject to recovery and management plans. The estimated fishing effort trends have formed the basis for the negotiations to fix fishing effort allocations to EU member states during the meetings of AGRIFISH.

Fishing effort trends have often been referred to in the annual European Commission's communications to the Council and the Parliament concerning consultations on fishing opportunities (e.g. for 2014, European Commission 2013). Recently, the data was used in the work allocating TAC adjustments between fleets falling subject to Article 15 of the CFP, the socalled landings obligation (STECF 2017b). Under interim arrangements lasting from 2015 to 2018, fleets and stocks were progressively brought under the landing obligation. At the same time, TACs for stocks that became subject to the landing obligation were adjusted (increased) in proportion to the forecast catch that would formerly have been discarded.

After verification by the JRC and STECF, processed, aggregated data are made available via an interactive online data dissemination platform developed by the JRC (see section 'Data dissemination and 
open data policy' below). However, although increasingly utilised for end uses outside of reporting on species management regimes, the origins of the data set entailed certain limitations, e.g. vessel length categories were not consistent with those used for the AER data set, restricting the ability to make use of the joint databases for bio-economic modelling. With new area-based multi-annual plans (MAPs) leading to the phased repeal of existing species management regimes, it was recognised that there was an opportunity to rationalise the database, make the changes necessary for compatibility with the AER data set and move to the collection of an EUwide data set of fishing capacity, effort, landings, and discards including data from the Mediterranean and distant fleets. In 2017, the new Fisheries Dependent Information (FDI) data call was launched. This call was used as a trial exercise to test whether the aspirations for the new data set could be realised and to refine the call and database where necessary. The conclusions drawn were positive, and the call will be conducted in 2018 as a full data call with anticipated dissemination of final data. There has been a deliberate attempt to make the new data set as generic as possible, in the hope it can fulfil multiple requirements from the EU as and when they arise.

\section{MEDITERRANEAN AND BLACK SEA STOCK ASSESSMENT DATA}

A first attempt to assess fish stocks in the Mediterranean Sea was made in the early 1970s by the scientific working groups of the GFCM (GFCM 1972). However, analytical assessments (i.e. incorporating the effects of fishing on the structure of the populations) were not carried out before the 1990s (Aldebert et al. 1993), mainly due to the lack of systematic data collection (Colloca et al. 2013). In the Black Sea, the first attempts were only undertaken in 1991. Moreover, between 1995 and 2008, there were no regional assessments conducted either for the Mediterranean or for the Black Sea (STECF 2008). In the early 2000s, enforcement of the EU DCR in all EU member states standardised the collection of fishery-dependent data, thereby providing the basis for analytical stock assessments. In 2007, the European Commission's Directorate-General for fisheries and maritime affairs (DG FISH; since March 2008, DG MARE) concluded that assessments and advice for Mediterranean fish stocks needed to be improved. At that time, assessments were undertaken only for a relatively small number of commercially important stocks, which had limited geographical ranges and were exploited by a small number of fleets (STECF 2008). Furthermore, because only a few scientific experts were involved in the GFCM's Scientific Advisory Committee (SAC), the capability of the SAC to provide comprehensive advice on the management of Mediterranean fisheries was rather limited. In 2008, the European Commission requested STECF to convene the first of a series of annual EWGs to assess the status of demersal and small pelagic stocks in the Mediterranean and Black Seas, and to provide fisheries management advice. STECF was also requested to develop and set up a framework for advising on low-risk adaptive management for EU fisheries, taking into account appropriate risk assessment methods, utilising data collected by EU member states under the DCR. To this end, the European Commission launched a series of data calls to EU member states requesting submission of relevant fisheries data. Since 2008, 29 EWG meetings have been convened to assess the status of Mediterranean and Black Sea stocks (https://stecf.jrc.ec.europa.eu/reports/medbs) (most recent reports: STECF 2017c for the Mediterranean, and STECF 2017d for Black Sea stocks).

\section{DATA DISSEMINATION AND OPEN DATA POLICY}

After verification by JRC and the STECF, the data tables that underpin the findings in the STECF's fleet, fish processing industry and aquaculture economic reports, the fisheries assessment reports, and the Mediterranean and Black Seas stock assessment reports are made available on the STECF website via an interactive data dissemination tool developed by the JRC (https://stecf.jrc.ec.europa.eu/data-dissemination). Dissemination of the data has proven to be extremely popular in that they have formed the basis of numerous scientific papers and reports. Examples are Marchal et al. (2016) and Walker et al. (2017) for fisheries assessment data, and Vasilakopoulos et al. (2014), Fernandes et al. (2017), and Rosenberg et al. (2018) for Mediterranean and Black Sea stock assessment data. In addition to this, in March 2017 the JRC released a public dashboard (https://stecf.jrc.ec. europa.eu/dd/medbs/ram) displaying time series of outputs from assessments of Mediterranean and Black Sea stocks (recruitment, spawning stock biomass, catch and fishing mortality reference points). The target audience of the dashboard includes governments, fisheries institutes, regional fisheries organisations, stakeholders, NGOs, academia, and 
common citizens that want to check the status of marine fish stocks.

As stated in Article 6 of the 2016 Decision on STECF (European Commission 2016a), reports of the STECF shall be made publicly available, except where disclosure of a document would undermine the protection of a public or private interest as defined in Article 4 of Regulation (EC) No 1049/2001 (European Communities 2001). As a DirectorateGeneral of the European Commission, the JRC is subject to the Commission's open access policy that stipulates that research data collected under the Horizon 2020 (H2020) programme must be freely accessible. Although the aggregated fisheries data used in the STECF process are not collected under the EU research and innovation programme H2020 (2014-2020) umbrella but under the DCR/DCF, the JRC has adopted an open access policy for such data. This approach is to ensure transparency and reproducibility and to facilitate further analyses by any interested parties. The aggregated data made available to the STECF under the DCF is publicly disseminated in 2 main ways: (1) contained in the reports of the STECF, either as tables in the reports themselves or as electronic annexes (Excel spreadsheets), or (2) via the online fisheries data dissemination tool developed by the JRC. Both the reports of the STECF and the online data dissemination tool can be accessed via the STECF website (https://stecf.jrc.ec.europa. eu/reports and https://stecf.jrc.ec.europa.eu/datadissemination, respectively). The dissemination of the aggregated data called in support of the work of the STECF has proven to be useful to a wide range of stakeholders, such as NGOs, governmental and intergovernmental institutions, the fisheries and aquaculture industries, and any other interested citizen (European Commission 2017). They have also been a highly valuable source of information for fisheries, environmental, economic and social scientists, and have increasingly been used as the basis for numerous peer-reviewed scientific publications (e.g. Colloca et al. 2013, Vasilakopoulos et al. 2014, Fernandes et al. 2017).

In addition to complying with the European Commission's open data policy, the JRC also provides assistance and clarification in response to queries from interested users of the data. Such support to data users, provided by the same JRC scientists who participate in STECF EWGs, aims to ensure that the data are not misinterpreted or misused. Nevertheless, the open data policy is not problem-free. Most of the data are disseminated in aggregated form, and while considerable efforts are made to ensure the data are not open to interpretation, for some complex data sets, this is not always the case. Thus, there is a risk that the data could be misinterpreted or used out of context, and it is important to check the EWG reports where data issues are detailed. Data used in support of scientific advice for fisheries management is by nature rather technical and is primarily required to address specific requests for advice. Consequently, the data that are made available online may not be the most appropriate basis for analyses other than those they were called for. An example is given by the STECF fishing effort and FDI reports and associated data annexes available via the data dissemination tool (https://stecf.jrc.ec.europa.eu/dd/ effort). The underlying data were requested in order to evaluate and advise on the monitoring and implementation of fishing effort regimes established under the CFP, and to provide a unique and extremely valuable time series of detailed spatial and temporal data on fishing activity for the EU fishing fleet. However, the data are processed and aggregated according to the regulatory perspective of fishing effort regimes, and the areas to which such regimes relate do not necessarily coincide with established fisheries management units. This means that without a detailed knowledge of the aggregation procedures adopted, there is a risk that some data variables may be inappropriately used and/or interpreted, despite being accompanied by contextual information and relevant disclaimers.

A further concern regarding public dissemination of DCF data processed by the JRC and STECF relates to the common misconception among some data users that the JRC and STECF are primarily responsible for the accuracy, quality and completeness of such data. This is not the case, as those responsibilities lie with the EU member states who own and provide the data. A further risk for inappropriate use or misuse of data relates to a lack of understanding that older versions of published data become redundant as soon as later versions become available. Finally, it should be noted that the JRC and STECF's open data policy is rather resource-intensive in terms of staff and time needed to make the data available, maintain the databases and handle miscellaneous enquiries. In a time of decreasing European Commission staff, JRC scientists have had to deal with an ever-increasing number of demands for additional services, which at times exceeds the available capacity. Moreover, the primary task of JRC scientists as defined by the JRC's corporate mission statement is carrying out research in order to provide independent scientific advice and support to EU policy. 
The open data policy adopted by the JRC and STECF is undoubtedly ethically correct, and despite the challenges described above, has proven to be very successful in serving the interests of the public, the fishing industry, NGOs, policy-makers and the scientific community. However, an open data policy, while ethically appropriate, is not cost-free, and the cost and benefits of increased availability and transparency of data together with increased public engagement need to be assessed by all institutions that adopt such a policy.

\section{CONCLUDING REMARKS}

Over the past $12 \mathrm{yr}$, data collected and provided under the DCF have been extensively used in support of the EU fisheries management decision-making process. While such data have been requested by numerous end-users such as ICES, GFCM and other RFMOs, the variety of requests for advice to the STECF from DG MARE has perhaps required the most diverse use of DCF data collected to date. To this end, in collaborating with and in support of the STECF, and DG MARE, and also the member states, the JRC input has been fundamental to the successful collation and management of data submitted by member states and in the development and maintenance of relevant fishery-dependent databases for fisheries in the Northeast Atlantic, the Eastern Arctic and the Baltic Sea (FAO area 27), databases for Mediterranean and Black Sea stock assessments, and economic databases on the EU fishing fleet, aquaculture and fish processing sectors. The data dissemination facility provided has generated much interest, and numerous bodies including the European Commission, academia, the fishing industry, member states' national administrations, regional fisheries bodies and NGOs have all viewed or downloaded data to conduct their own investigations and analyses.

The time series of data stored in the databases held by the JRC provide a unique record of EU-wide fisheries data at a level of aggregation that is unavailable elsewhere and which in principle can be used to undertake assessments and evaluations that would not be possible on such a wide scale using other available data sets. However, despite improvements both in data coverage and quality as the DCF has evolved, significant gaps in data for some variables remain, especially in relation to information on discards. Hence, users of the data that are freely disseminated via the JRC data dissemination tool should be aware that in some cases, information may be incomplete and conclusions drawn from analyses of such data may not be valid unless the user has a thorough understanding of how the raw data were collected and how the aggregated data were derived.

Looking to the future, the DCF is gradually evolving to incorporate coordination of data collection at the regional scale. The motivation is to rationalise the collection of fisheries data by sharing the burden between member states. If implemented successfully, such an approach should provide much of the data and information that is currently missing. In a climate where requests for advice on fisheries management to the STECF are not only increasing, but are also becoming more diverse, the demands on data collected under the DCF are likely to become even more varied and the maintenance and improvement of the databases managed by the JRC will undoubtedly continue to be fundamental to the ability of the STECF and others to respond to such requests.

Acknowledgements. All authors provided expert participation either to the STECF or its Expert Working Groups over the period reported in the paper. J.C. and N.G. are former chairs of the Committee. With the exception of N.G., all authors were at some stage over the reported period involved in JRC/STECF secretariat and/or data collection activities as JRC staff or seconded national expert (H.-J.R.). The authors thank all past and present STECF members and invited experts for their dedication, commitment, and camaraderie over the past years. Thanks are also extended to all DG MARE focal points and to JRC colleagues past and present for both their scientific input and administrative support to STECF activities.

\section{LITERATURE CITED}

Aldebert Y, Recasens L, Lleonart J (1993) Analysis of gear interactions in a hake fishery: the case of the Gulf of Lions (NW Mediterranean). Sci Mar 57:207-217

* Bjørndal T, Brasão A, Ramos J, Tusvik A (2016) Fish processing in Portugal: an industry in expansion. Mar Policy 72: 94-106

Bostock J, Lane A, Hough C, Yamamoto K (2016) An assessment of the economic contribution of EU aquaculture production and the influence of policies for its sustainable development. Aquac Int 24:699-733

* Cardinale M, Dörner H, Abella A, Andersen JL and others (2013) Rebuilding EU fish stocks and fisheries, a process under way? Mar Policy 39:43-52

Cheilari A, Guillen J, Damalas D, Barbas T (2013) Effects of the fuel price crisis on the energy efficiency and the economic performance of the European Union fishing fleets. Mar Policy 40:18-24

Colloca F, Cardinale M, Maynou F, Giannoulaki M and others (2013) Rebuilding Mediterranean fisheries: a new paradigm for ecological sustainability. Fish Fish 14: 89-109 
Council of the European Communities (1983) Council Regulation (EEC) No 170/83 of 25 January 1983 establishing a Community system for the conservation and management of fishery resources. Off $\mathrm{J}$ Eur Union $\mathrm{L}$ 24:1-13

EU (European Union) (2000) European Council Regulation (EC) No 1543/2000 of 29 June 2000 establishing a Community framework for the collection and management of the data needed to conduct the common fisheries policy. Off J Eur Union L 176:1-16

EU (2002a) European Council Regulation (EC) No 2371/ 2002 of 31 December 2002 on the conservation and sustainable exploitation of fisheries resources under the Common Fisheries Policy. Off J Eur Union L 358:59-80

EU (2002b) European Council Regulation (EC) No 2347/ 2002 of 16 December 2002 establishing specific access requirements and associated conditions applicable to fishing for deep sea stocks. Off J Eur Union L 351:6-11

EU (2003) European Council Regulation (EC) No 1954/2003 of 4 November 2003 on the management of the fishing effort relating to certain Community fishing areas and resources and modifying Regulation (EC) No 2847/93 and repealing Regulations (EC) No 685/95 and (EC) No 2027/95. Off J Eur Union L 289:1-7

EU (2004) European Council Regulation (EC) No 423/2004 of 26 February 2004 establishing measures for the recovery of cod stocks. Off J Eur Union L 70:8-11

EU (2005) Council Regulation (EC) No 2166/2005 of 20 December 2005 establishing measures for the recovery of the Southern hake and Norway lobster stocks in the Cantabrian Sea and Western Iberian Peninsula and amending Regulation (EC) No 850/98 for the conservation of fishery resources through technical measures for the protection of juveniles of marine organisms. Off J Eur Union L 345:5-10

EU (2006) Council Regulation (EC) No 388/2006 of 23 February 2006 establishing a multiannual plan for the sustainable exploitation of the stock of sole in the Bay of Biscay. Off J Eur Union L 65:1-4

EU (2007a) Treaty of Lisbon amending the treaty on European Union and the Treaty establishing the European Community. Off J Eur Union C 306:1-271

EU (2007b) Council Regulation (EC) No 676/2007 of 11 June 2007 establishing a multi annual plan for fisheries exploiting stocks of plaice and sole in the North Sea. Off J Eur Union L 157:1-6

EU (2007c) Council Regulation (EC) No 509/2007 of 7 May 2007 establishing a multi-annual plan for the sustainable exploitation of the stock of sole in the Western Channel. Off J Eur Union L 122:7-10

EU (2007d) Council Regulation (EC) No 1098/2007 of 18 September 2007 establishing a multiannual plan for the cod stocks in the Baltic Sea and the fisheries exploiting those stocks, amending Regulation (EEC) No 2847/93 and repealing Regulation (EC) No 779/97. Off J Eur Union L 248:1-10

EU (2008a) European Council Regulation (EC) No 199/2008 of 25 February 2008 concerning the establishment of a Community framework for the collection, management and use of data in the fisheries sector and support for scientific advice regarding the Common Fisheries Policy. Off J Eur Union L 60:1-12

EU (2008b) European Council Regulation (EC) No 1342/2008 of 18 December 2008 establishing a long-term plan for cod stocks and the fisheries exploiting those stocks and repealing Regulation (EC) No 423/2004. Off J Eur Union L 348:20-33

EU (2013) Regulation (EU) No 1380/2013 of the European Parliament and of the Council of 11 December 2013 on the Common Fisheries Policy, amending Council Regulations (EC) No 1954/2003 and (EC) No 1224/2009 and repealing Council Regulations (EC) No 2371/2002 and (EC) No 639/2004 and Council Decision 2004/585/EC. Off J Eur Union L 354:22-61

EU (2014) Regulation (EU) No 508/2014 of the European Parliament and of the Council of 15 May 2014 on the European Maritime and Fisheries Fund and repealing Council Regulations (EC) No 2328/2003, (EC) No 861/ 2006, (EC) No 1198/2006 and (EC) No 791/2007 and Regulation (EU) No 1255/2011 of the European Parliament and of the Council. Off J Eur Union L 149:1-66

EU (2016) Guide to the ordinary legislative procedure. Publications Office of the European Union, Luxembourg

European Commission (1979) Commission Decision of 8 June 1979 relating to the institution of a Scientific and Technical Committee for Fisheries (79/572/EEC). Off J Eur Union L 156:29-30

European Commission (1993) Commission Decision of 19 November 1993 relating to the institution of a Scientific, Technical and Economic Committee for Fisheries (93/ 619/EC). Off J Eur Union L 297:1-25

European Commission (2005a) Commission Decision of 26 August 2005 establishing a Scientific, Technical and Economic Committee for Fisheries (2005/629/EC). Off J Eur Union L 225:18-22

European Commission (2005b) Classification and analysis of the scientific domains covered by the biological studies 1997-2000 in support of the CFP. Directorate-General for Fisheries, Brussels

European Commission (2008) European Commission Decision (EC) No 949/2008 of 6 November 2008 adopting a multiannual Community programme pursuant to Council Regulation (EC) No 199/2008 establishing a Community framework for the collection, management and use of data in the fisheries sector and support for scientific advice regarding the Common Fisheries Policy. Off J Eur Union L 346:37-88

European Commission (2009) Commission Decision of 18 December 2009 adopting a multiannual Community programme for the collection, management and use of data in the fisheries sector for the period 2011-2013 (2010/93/ EU). Off J Eur Union L 41:8-71

European Commission (2011) Commission Implementing Regulation (EU) No 404/2011 of 8 April 2011 laying down detailed rules for the implementation of Council Regulation (EC) No 1224/2009 establishing a Community control system for ensuring compliance with the rules of the Common Fisheries Policy. Off J Eur Union L 112:1-153

European Commission (2013) Communication from the Commission to the Council concerning a consultation on fishing opportunities for 2014, 30.5.2013, COM(2013) 319 final. European Commission, Brussels

European Commission (2016a) Commission Decision of 25 February 2016 setting up a Scientific, Technical and Economic Committee for Fisheries (2016/C 74/05). Off J Eur Union C 74:4-10

European Commission (2016b) Commission Implementing Decision (EU) 2016/1251 of 12 July 2016 adopting a multiannual Union programme for the collection, man- 
agement and use of data in the fisheries and aquaculture sectors for the period 2017-2019 (notified under document C(2016) 4329). Off J Eur Union L 207: 113-177

European Commission (2017) The EU fishing fleet: trends and economic results. DG MARE Econ Pap no. 03/2017. Directorate-General for Maritime Affairs and Fisheries (DG MARE) and Joint Research Centre (JRC), Brussels. doi:10.2771/667047

European Communities (2001) Article 4 of Regulation (EC) No $1049 / 2001$ of the European Parliament and of the Council of 30 May 2001 regarding public access to European Parliament, Council and Commission documents. Off J Eur Union L 145:43

Fernandes PG, Ralph GM, Nieto A, Criado MG and others (2017) Coherent assessments of Europe's marine fishes show regional divergence and megafauna loss. Nat Ecol Evol 1:0170

GFCM (General Fisheries Council for the Mediterranean) (1972) Rapport de la troisieme session du Groupe de travail du CGPM sur 1'evaluation et 1'exploitation des ressources demersales, Athenes, 6-11 mars, 1972. GFCM, FAO, Rome (in French)

Guillen J, Santos AC, Carpenter G, Carvalho N and others (2016) Sustainability now or later? Estimating the benefits of pathways to maximum sustainable yield for EU Northeast Atlantic fisheries. Mar Policy 72:40-47

Hadjimichael M, Delaney A, Kaiser MJ, Edwards-Jones G (2013) How resilient are Europe's inshore fishing communities to change? Differences between the North and the South. Ambio 42:1037-1046

Jennings S, Stentiford GD, Leocadio AM, Jeffery KR and others (2016) Aquatic food security: insights into challenges and solutions from an analysis of interactions between fisheries, aquaculture, food safety, human health, fish and human welfare, economy and environment. Fish Fish 17:893-938

Lasner T, Brinker A, Nielsen R, Rad F (2017) Establishing a benchmarking for fish farming - profitability, productivity and energy efficiency of German, Danish and Turkish rainbow trout grow-out systems. Aquac Res 48: 3134-3148

Editorial responsibility: Konstantinos Stergiou, Thessaloniki, Greece
Marchal P, Andersen JL, Aranda M, Fitzpatrick M, Goti L, Guyader O (2016) A comparative review of fisheries management experiences in the European Union and in other countries worldwide: Iceland, Australia, and New Zealand. Fish Fish 17:803-824

Rosenberg AA, Kleisner KM, Afflerbach J, Anderson SC and others (2018) Applying a new ensemble approach to estimating stock status of marine fisheries around the world: estimating global fisheries status. Conserv Lett 11: e12363

STECF (Scientific, Technical and Economic Committee for Fisheries) (2008) Report of the SGMED-08-02 Working Group on the Mediterranean Part II. EUR 23669 EN, JRC 49329. Office for Official Publications of the European Communities, Luxembourg

STECF (2014) The economic performance report on the EU fish processing (STECF-14-21). EUR 27029 EN, JRC 93340. Publications Office of the European Union, Luxembourg

STECF (2016) The economic performance of the EU aquaculture sector (STECF 16-19). EUR 28356 EN. Publications Office of the European Union, Luxembourg

STECF (2017a) The 2017 annual economic report on the EU fishing fleet (STECF 17-12). Publications Office of the European Union, Luxembourg

STECF (2017b) Data and information requested by the Commission to support the preparation of proposals for fishing opportunities in 2018 (STECF-17-13). Publications Office of the European Union, Luxembourg

STECF (2017c) Mediterranean assessments 2017. Part 1. (STECF-17-15). Publications Office of the European Union, Luxembourg

STECF (2017d) Stock assessments in the Black Sea (STECF17-14). Publications Office of the European Union, Luxembourg

*Vasilakopoulos P, Maravelias CD, Tserpes G (2014) The alarming decline of Mediterranean fish stocks. Curr Biol 24:1643-1648

WWalker ND, Maxwell DL, Le Quesne WJF, Jennings S (2017) Estimating efficiency of survey and commercial trawl gears from comparisons of catch-ratios. ICES J Mar Sci 74:1448-1457

Submitted: August 2, 2017; Accepted: March 5, 2018 Proofs received from author(s): May 4, 2018 